theory that the movements of wasps are tropisms in the sense the term is used by Loeb; nor is it apparent how it can be the result of what Thorndike calls "trial and error" movements. Her whole behavior is that of a creature struggling, against obstacles, to attain a certain known place in a known environment.

\title{
DIPTEROLOGICAL NOTES.
}

\author{
By Charles W. Johnson. \\ Boston Society of Natural History. \\ Chionea valga Harris.
}

A specimen was found by Mr. J. H. Emerton while sifting for spiders at Tyngsboro, Mass., December 6, 1911. This date was more than three weeks prior to any snow in this section, and indicates that the appearance of this insect on snow is merely accidental. The imago probably emerges during the late fall and passes the winter in that state. The difficulty in seeing this wingless gnat excepting when it happens to crawl upon the snow, makes its life habits hard to study.

Cholomyia longipes Fabricius.

Musca longipes Fabr., Syst. Antl., p. 298, 1805.

Cholomyia inıquipes Bigot, Bull. Soc. Ent. France, Vol. IV, 6 ser., pt. 2, p. XXXVII, 1884.

Thelairodes basalis Giglio-Tos. Bull. R. Univ. Torino, VIII, No. 147, p. 3, 1893; Ditt. del Mess. III, p. 65, 1894.

While studying some South American diptera, my attention was called to a specimen which had been in my collection for some time that had been collected by Mr. E. Daecke at Richmond Hill, Long Island, N. Y., July 2, 1901. I was greatly surprised to find that it agreed with a specimen from the Caura Valley, Venezuela, collected by Mr. S. M. Klages. Recently Dr. O. A. Johannsen spoke of a specimen taken at Ithaca, N. Y., which he identified as C. incequipes Bigot, as figured by Van der Wulp (Biol. Cent. Amer. Dipt., II, 247, pl. 4, f. 1, 2.) This distribution is further augmented by specimens in the National Museum from Peaks of Otter, Va. (W. Palmer); Mo. (from Conotrachelus); and Marion, La., bred 
from Conotrachelus juglandis. Another feature which is brought to light is that all the $C$. longipes are males, while of the specimens of Thelairodes basalis with a similar distribution are females. The latter has been recorded from Dover and Orange Mts., N. J., and specimens are in the National Museum from Lexington, Ky., and Lawrence, Kans.

Similar records of wide distribution of species of Dexiidæ are not uncommon. Euantha liturata Oliv. (Dexia dives Wied.) extends from Guatemala to New Jersey. Cordyligaster minuscula V. d. Wulp, (C. septentrionalis Towns.) Mexico to Virginia and Maryland. Dexia vertebrata Say., New Hampshire to Florida and westward to Arizona. Thelairodes cineriicollis V. d. Wulp, Mexico to New Jersey. That $C$. incequipes Bigot, is the same as longipes Fabr. there seems to be no doubt.

Wohlfahrtia opaca Coquillett.

Paraphyto opaca Coq., Revis. Tachin., p. 123, 1897.

The presence of this genus in North America has been known to the writer for a long time, but the determination of the species was quite a different matter, as few realized that it had already been described as a Tachinid under the genus Paraphyto. This error together with others which unavoidably entered into the first attempt of a work of the magnitude of the "Revision of the Tachinidæ of America north of Mexico," had been discovered by Mr. Coquillett, and it is to be greatly regretted that he was unable to make a revised edition of this most comprehensive and valuable work ever published in the North American Tachinidæ.

Sometime ago I received from Professor S. Arthur Johnson, three specimens of this species collected at Fort Collins, Col., May 8 and June 21, 1901. Recently I received from Dr. E. G. Titus five specimens collected at Logan, Utah, April 20, 1908; Lehi, Utah, July 1, 1908, and Cache Junction, Utah, May 1, 1906.

Coquillett in his "Type-species of the North America Genera of Diptera," makes Wohlfahrtia a synonym of Sarcophila. As the two genera are considered distinct by European authors, I prefer to treat them accordingly. The species agree quite well with the description of $W$. meigenii of Europe, but a comparison of specimens is necessary for accuracy. 
In regard to the Sarcophaga carnaria recorded in the New Jersey list I intended to have the name questioned, but it was in some way overlooked. The record is based on a large species $(14 \mathrm{~mm}$.) having black genitalia, and a long fringe of hairs on the posterior tibiæ; it closely resembles the S. carnaria of Europe but lacks the anterior acrosticals and dorsocentrals. The species seems to be confined to the immediate sea-shore of New Jersey, and has also been found in similar situations at Chatham (June 30), Wollaston (September 5), and Plum Island, Mass. (July 17). The latter were collected by Mr. A. P. Morse.

The Sarcophaga "georgiana" of the New Jersey list is a large species $(13 \mathrm{~mm}$.) with reddish genitalia and a long fringe of hairs on the posterior tibiæ. Whether it is the true S. georgina Wied. I cannot say as his description is inadequate. The latter is the proper form for the name.

\section{COCCINELLA UNDECIMPUNCTATA LINN. IN MASSACHUSETTS.}

By Charles Schaeffer, Museum of Brooklyn Institute, Brooklyn, N. Y.

While in Boston recently, Mr. Charles W. Johnson gave me two specimens of a Coccinella of which he had taken several, Sept. 5th in Wollaston, Massachusetts, for which he said he could get no name.

The species proved to be Coccinella undecimpunctata Linn. a European species given with the var. menetriesi Muls. in Henshaw's "Third Supplement to the Coleoptera."

Mr. Casey, in his Revision of the American Coccinellidæ in Journ. N. Y. Ent. Soc. vol. VII, p. 71, omits the species entirely. Mr. Leng in the same publication vol. XI, p. 201, gives a description and distribution of the var. menetriesi Muls. However, he said, that though it was described from California, the species should be dropped as there were no other records of its occurrence in America.

The species is an easily recognized one. The form is less convex than the other North American species of the genus and more 

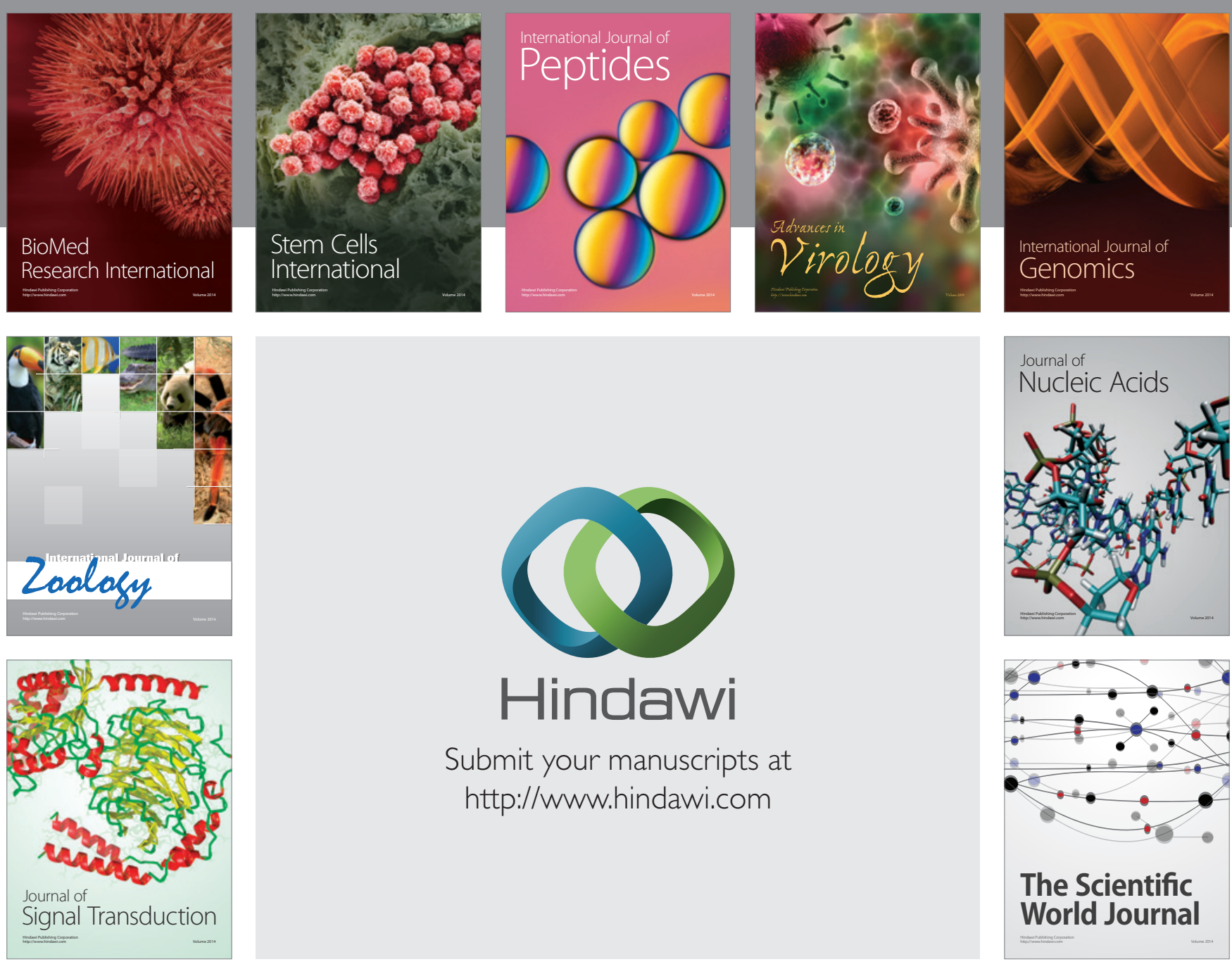

Submit your manuscripts at

http://www.hindawi.com
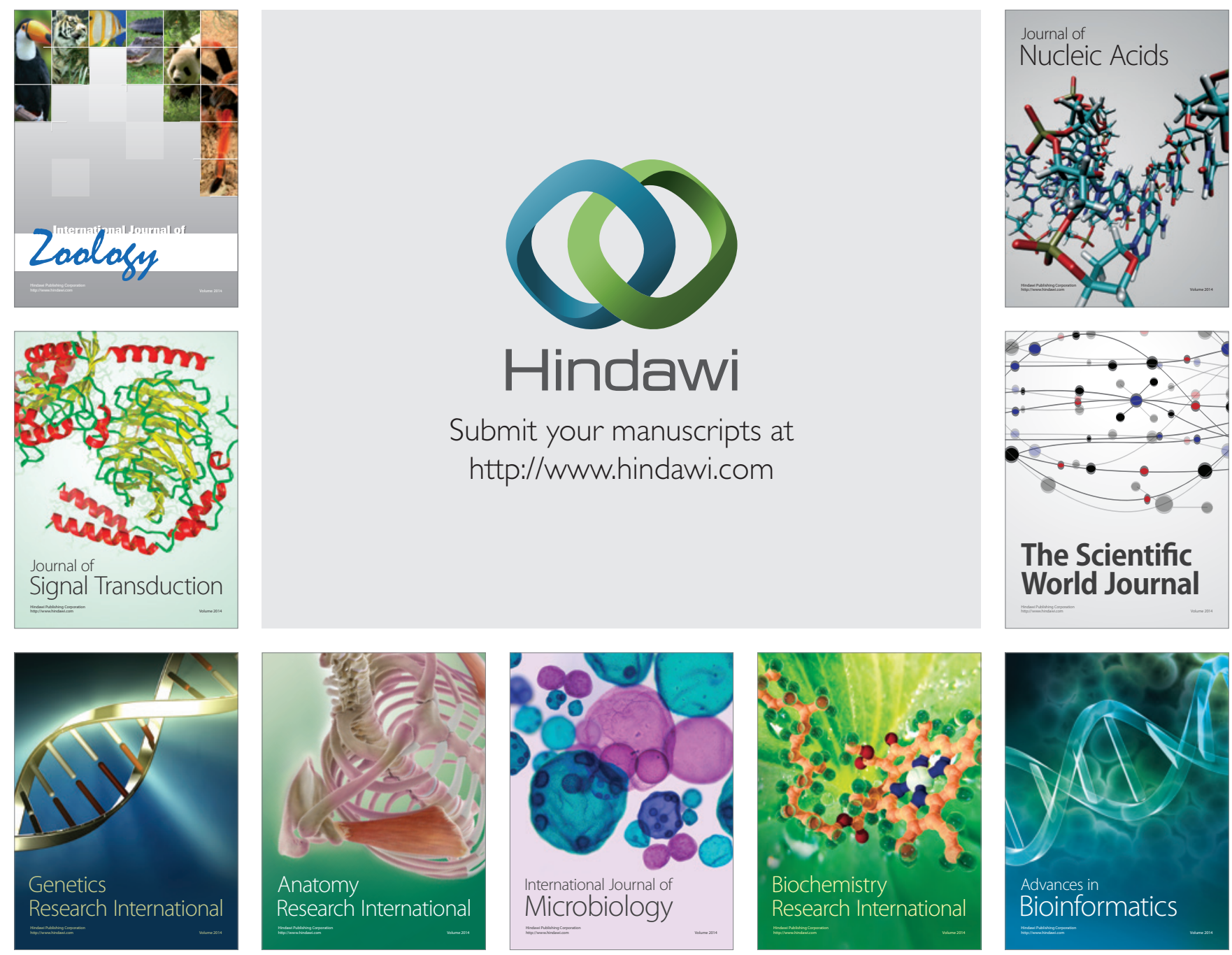

The Scientific World Journal
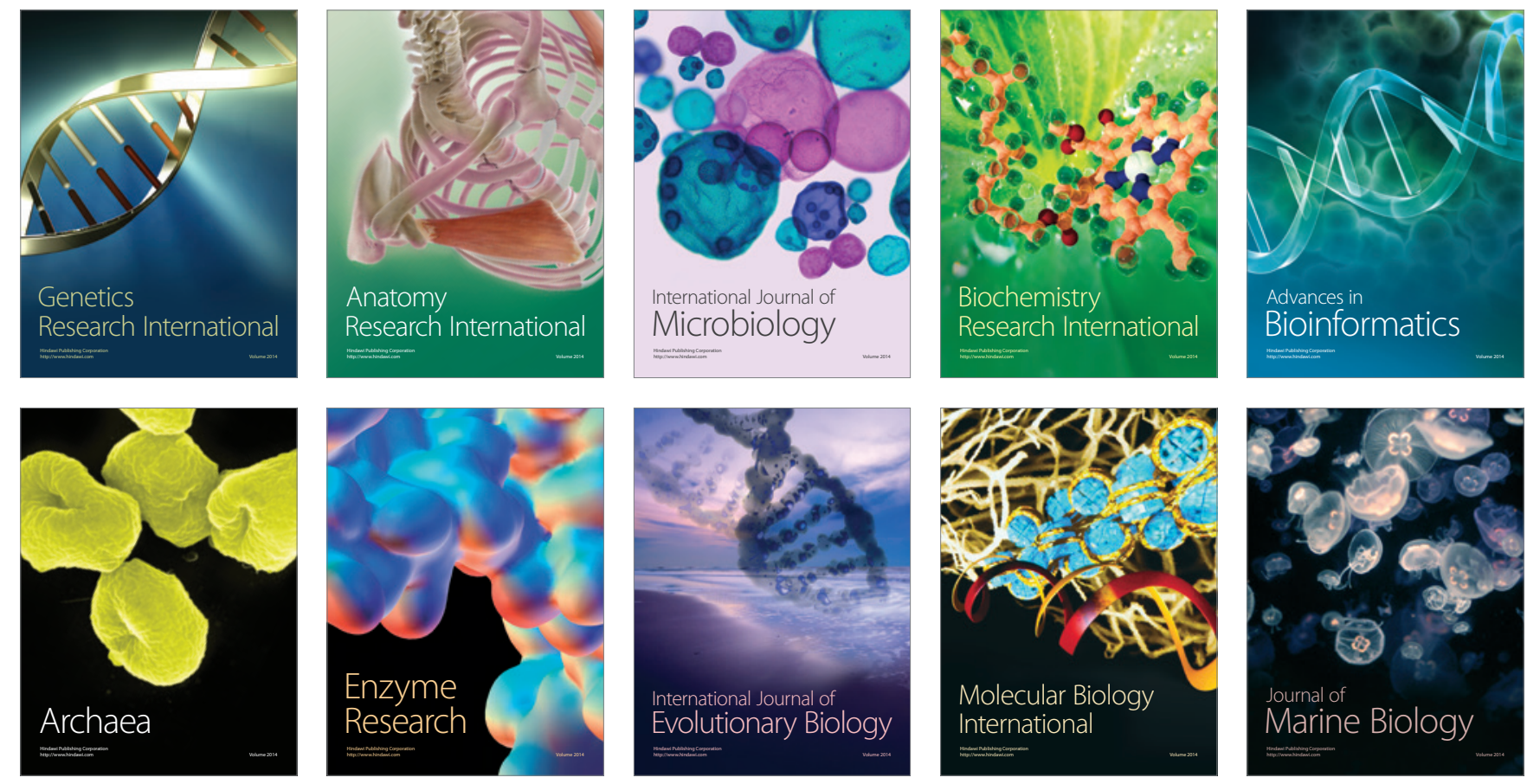